Abstracta Iranica Abstracta Iranica

Revue bibliographique pour le domaine irano-aryen

Volume 25 | 2004

Comptes rendus des publications de 2002

\title{
« Novelty and tradition in Achaemenid Syria: The case of the clay 'Astarte' plaques ». Iranica Antiqua XXXVII, pp. 203-218.
}

\section{Astrid Nunn}

\section{(2) OpenEdition}

12 Journals

Édition électronique

URL : http://journals.openedition.org/abstractairanica/4283

DOI : 10.4000/abstractairanica.4283

ISSN : 1961-960X

Éditeur :

CNRS (UMR 7528 Mondes iraniens et indiens), Éditions de l'IFRI

\section{Édition imprimée}

Date de publication : 15 mai 2004

ISSN : 0240-8910

Référence électronique

Astrid Nunn, « « Novelty and tradition in Achaemenid Syria: The case of the clay 'Astarte' plaques ». Iranica Antiqua XXXVII, pp. 203-218. », Abstracta Iranica [En ligne], Volume 25 | 2004, document 72, mis en ligne le 15 mars 2006, consulté le 25 septembre 2020. URL : http://journals.openedition.org/ abstractairanica/4283 ; DOI : https://doi.org/10.4000/abstractairanica.4283

Ce document a été généré automatiquement le 25 septembre 2020.

Tous droits réservés 
« Novelty and tradition in Achaemenid Syria: The case of the clay 'Astarte' plaques ». Iranica Antiqua XXXVII, pp. 203-218.

\author{
Astrid Nunn
}

Plusieurs articles traitent des "plaques d'Astarté », terres cuites représentant une femme vue de face, vêtue ou dévêtue (cf. Abs. Ir. 23, 2000, n 80). L'A. propose une nouvelle approche en partant du matériel récemment fouillé et donc mieux documenté du Tell Mastuma en Syrie. Les plaques trouvées dans un contexte domestique montrent des femmes dévêtues. Celles montrant des femmes vêtues sont en général brisées au cou. Toutes peuvent être associées au «cavalier perse». Certes il est impossible d'identifier ces femmes: déesses ou orantes, la question reste ouverte, même si l'A. opte pour la seconde possibilité.

\title{
INDEX
}

Thèmes : 3.2.2. Pré-Achéménides et Achéménides

\section{AUTEURS}

\section{ASTRID NUNN}

Université de Munich 